\title{
BMJ
}

\section{Long term pharmacotherapy for obesity and overweight: updated meta-analysis}

\author{
Diana Rucker, clinical fellow, ${ }^{1}$ Raj Padwal, assistant professor, ${ }^{1}$ Stephanie K Li, assistant clinical professor, \\ Cintia Curioni, assistant professor, ${ }^{2}$ David C W Lau, professor $^{3}$
}

'Department of Medicine, University of Alberta, Edmonton, $\mathrm{AB}$, Canada

${ }^{2}$ Department of Nutrition Faculdade Arthur Sá Earp Neto, Petrópolis, Rio de Janeiro, Brazil

${ }^{3}$ Department of Medicine, University of Calgary, Calgary, $\mathrm{AB}$, Canada

Correspondence to: R Padwal rpadwal@ualberta.ca

doi:10.1136/bmj.39385.413113.25

\section{ABSTRACT}

Objective To summarise the long term efficacy of antiobesity drugs in reducing weight and improving health status.

Design Updated meta-analysis of randomised trials. Data sources Medline, Embase, the Cochrane controlled trials register, the Current Science meta-register of controlled trials, and reference lists of identified articles. All data sources were searched from December 2002 (end date of last search) to December 2006.

Studies reviewed Double blind randomised placebo controlled trials of approved anti-obesity dugs used in adults (age over 18) for one year or longer.

Results 30 trials of one to four years' duration met the inclusion criteria: 16 orlistat ( $n=10631$ participants), 10 sibutramine $(n=2623)$, and four rimonabant $(n=6365)$. Of these, 14 trials were new and 16 had previously been identified. Attrition rates averaged 30-40\%. Compared with placebo, orlistat reduced weight by $2.9 \mathrm{~kg}$ ( $95 \%$ confidence interval $2.5 \mathrm{~kg}$ to $3.2 \mathrm{~kg}$ ), sibutramine by $4.2 \mathrm{~kg}$ (3.6 kg to $4.7 \mathrm{~kg}$ ), and rimonabant by $4.7 \mathrm{~kg}$ ( $4.1 \mathrm{~kg}$ to $5.3 \mathrm{~kg}$ ).

Patients receiving active drug treatment were significantly more likely to achieve $5 \%$ and $10 \%$ weight loss thresholds. Orlistat reduced the incidence of diabetes and improved concentrations of total cholesterol and low density lipoprotein cholesterol, blood pressure, and glycaemic control in patients with diabetes but increased rates of gastrointestinal side effects and slightly lowered concentrations of high density lipoprotein. Sibutramine lowered concentrations of high density lipoprotein cholesterol and triglycerides but raised blood pressure and pulse rate. Rimonabant improved concentrations of high density lipoprotein cholesterol and triglycerides, blood pressure, and glycaemic control in patients with diabetes but increased the risk of mood disorders.

Conclusions Orlistat, sibutramine, and rimonabant modestly reduce weight, have differing effects on cardiovascular risk profiles, and have specific adverse effects.

\section{INTRODUCTION}

Obesity and overweight are highly and increasingly prevalent chronic conditions currently affecting over 1.1 billion individuals worldwide and are associated with premature mortality, chronic morbidity, and increased healthcare use. ${ }^{12}$ Recently published guidelines recommend lifestyle modification as the initial treatment for obesity and suggest that adjunctive drug treatment is considered in patients with a body mass index $\geq 30$ or 27-29.9 with medically complicated obesity. ${ }^{2}$ Orlistat, a gastrointestinal lipase inhibitor, sibutramine, a centrally acting monoamine reuptake inhibitor, and rimonabant, an endocannabinoid receptor antagonist, are approved for long term treatment of obesity (one year or more). ${ }^{3}$

Treatment with anti-obesity drugs is common, with global sales in 2005 estimated at $\$ 1.2 \mathrm{bn} .{ }^{4}$ As weight losses achieved with lifestyle intervention are modest and limited by high rates of recidivism and compensatory slowing of metabolism, ${ }^{56}$ there is potential for even greater use of drug treatment. Furthermore, as the prevalence and incidence of obesity grow and as newer agents are developed, use of these drugs will probably increase further.

We carried out an updated systematic review and meta-analysis to quantify the efficacy of and adverse effects associated with the long term use of anti-obesity drugs. This paper is a summary of a recently updated Cochrane collaboration systematic review. ${ }^{?}$

\section{METHODS}

Inclusion and exclusion criteria and outcomes

With the help of a medical librarian we searched Medline, Embase, the Cochrane controlled trials register, and the metaregister of controlled trials (www.con trolled-trials.com) from December 2002 to December 2006 and examined reference lists of identified articles. In the original version of this review, the search covered the period from the inception of each database to December 2002. ${ }^{8}$ We searched for placebo controlled clinical trials of at least one year in duration that evaluated the effects of anti-obesity drugs on weight, cardiovascular risk factors, cardiovascular morbidity and mortality, and overall mortality. A subgroup analysis examined weight loss and glycaemic control in patients with type 2 diabetes. All trials had to be double blind (patient and care provider) randomised controlled trials examining overweight or obese adults (age 18 years or over) that used intention to treat analysis. Quasi-randomised, open label crossover trials and studies published only in abstract form were not included. There were no language restrictions. 


\section{Selection and data extraction}

Two unblinded reviewers performed electronic searches and screened the initial results. Articles that clearly did not meet inclusion criteria were rejected on initial review. If uncertainty existed, the full text of the article was reviewed. Two reviewers independently assessed all potentially relevant studies for inclusion and extracted and recorded data. Disagreements were resolved by consensus. Agreement between raters was assessed with Cohen's $\kappa$ coefficient. If the published article provided inadequate information for a given end point, we contacted the primary author. We also approached pharmaceutical companies for missing data elements and information on unpublished trials.

\section{Assessment of quality}

Two authors independently scored the nine criteria of the Verhagen Delphi list to assess quality. ${ }^{9}$ This was reported in a descriptive fashion rather than using a numerical quality score because such scores can be inaccurate and poorly reproducible when they are used to differentiate between high and low quality studies. ${ }^{10}$ Further details can be found in the full Cochrane review. $^{7}$

\section{Measures of treatment effect, heterogeneity, and publication bias}

We calculated difference in risk for dichotomous out comes and weighted mean differences for continuous outcomes at the end of follow-up. When studies reported results for different doses, we abstracted the dose most commonly used in clinical practice (orlistat $120 \mathrm{mg}$ three times a day, sibutramine $15 \mathrm{mg}$ daily, and rimonabant $20 \mathrm{mg}$ daily). Quantitative analyses of outcomes were based on intention to treat results. In studies with high attrition rates, we preferentially abstracted results

\begin{tabular}{|c|c|c|c|c|c|c|c|}
\hline & Study population & $\begin{array}{l}\text { Mean age } \\
\text { (years) }\end{array}$ & $\begin{array}{c}\text { Mean } \\
\text { BMI }\end{array}$ & $\begin{array}{l}\text { Mean weight } \\
(\mathrm{kg})\end{array}$ & Comparison & $\begin{array}{c}\text { Attrition (\% } \\
\text { drug/placebo) }\end{array}$ & Cointerventions \\
\hline Bakris $^{w 1}$ & $\begin{array}{l}554 \text { with hypertension, } 1 \text { year follow- } \\
\text { up, (US) }\end{array}$ & 53 & 35.6 & 101 & $\begin{array}{l}\text { Orlistat } 120 \text { mg three times daily } \\
(n=278) ; \text { placebo }(n=276)\end{array}$ & $42 / 61$ & $\begin{array}{l}2.5 \mathrm{MJ} / \text { day deficit diet; } \\
\text { educational literature }\end{array}$ \\
\hline Berne $^{\text {w2 }}$ & $\begin{array}{l}220 \text { with type } 2 \text { diabetes receiving oral } \\
\text { hypoglycaemics, } 1 \text { year follow-up } \\
\text { (Sweden) }\end{array}$ & 59 & 32.7 & 96 & $\begin{array}{l}\text { Orlistat } 120 \mathrm{mg} \text { three times daily } \\
(n=111) ; \text { placebo }(n=109)\end{array}$ & $14 / 14$ & $\begin{array}{l}2.5 \mathrm{MJ} / \text { day deficit diet; } \\
\text { exercise counselling; } \\
\text { educational package }\end{array}$ \\
\hline Broom $^{\mathrm{w} 3}$ & $\begin{array}{l}531 \text { with hypertension, impaired } \\
\text { glucose tolerance, or dyslipidaemia, } \\
1 \text { year follow-up (UK) }\end{array}$ & 46 & 37.1 & 101 & $\begin{array}{l}\text { Orlistat } 120 \mathrm{mg} \text { three times daily } \\
(n=265) ; \text { placebo }(n=266)\end{array}$ & $30 / 40$ & $\begin{array}{l}2.5-3.8 \mathrm{MJ} / \text { day deficit diet; } \\
\text { food diary }\end{array}$ \\
\hline Davidson $^{\text {w4 }}$ & $\begin{array}{l}892 \text { followed for } 1 \text { year and a second } \\
\text { weight maintenance year, (UK) }\end{array}$ & 46 & 37.1 & 101 & $\begin{array}{l}\text { Orlistat } 120 \text { mg three times daily } \\
(n=668) ; \text { placebo }(n=224)\end{array}$ & $31 / 41$ & $\begin{array}{l}\text { 2.5-3.3 MJ/day deficit diet; } \\
\text { exercise counselling' food } \\
\text { diary }\end{array}$ \\
\hline Derosaw5 $^{\text {w }}$ & $\begin{array}{l}50 \text { with dyslipidaemia, } 1 \text { year follow-up } \\
\text { (Italy) }\end{array}$ & 52 & 31.9 & 95 & $\begin{array}{l}\text { Orlistat } 120 \mathrm{mg} \text { three times daily } \\
(n=27) ; \text { placebo }(n=23)\end{array}$ & $7 / 0$ & $6.3 \mathrm{MJ} /$ day deficit diet \\
\hline Finer $^{w 6}$ & 228 followed for 1 year (UK) & 41 & 36.8 & 98 & $\begin{array}{l}\text { Orlistat } 120 \mathrm{mg} \text { three times daily } \\
(\mathrm{n}=114) ; \text { placebo }(n=114)\end{array}$ & $36 / 42$ & 2.5-3.8 MJ/day deficit diet \\
\hline Hauptmanw7 & $\begin{array}{l}635 \text { followed for } 1 \text { year and a second } \\
\text { weight maintenance year (US) }\end{array}$ & 42 & 36 & 101 & $\begin{array}{l}\text { Orlistat } 60 \mathrm{mg} \text { three times daily } \\
(n=213) ; \text { orlistat } 120 \text { mg three } \\
\text { times daily }(n=210) ; \text { placebo } \\
(n=212)\end{array}$ & $28 / 28 / 42$ & $\begin{array}{l}\text { 5.0-6.3 MJ/day diet; exercise; } \\
\text { food diary; educational video }\end{array}$ \\
\hline Hollander $^{\text {w8 }}$ & $\begin{array}{l}322 \text { with type } 2 \text { diabetes, } 1 \text { year follow- } \\
\text { up (US) }\end{array}$ & 55 & 34.3 & 100 & $\begin{array}{l}\text { Orlistat } 120 \mathrm{mg} \text { three times daily } \\
(n=63) ; \text { placebo }(n=159)\end{array}$ & $15 / 28$ & $2.1 \mathrm{MJ} /$ day deficit diet \\
\hline Kelley $^{\text {w9 }}$ & $\begin{array}{l}550 \text { with type } 2 \text { diabetes, } 1 \text { year follow- } \\
\text { up (US) }\end{array}$ & 58 & 35.7 & 102 & $\begin{array}{l}\text { Orlistat } 120 \text { mg three times daily } \\
(n=274) ; \text { placebo }(n=276)\end{array}$ & $50 / 54$ & $\begin{array}{l}2.5-3.3 \mathrm{MJ} / \text { day deficit diet; } \\
\text { exercise counselling; food } \\
\text { records }\end{array}$ \\
\hline Krempf $^{w 10}$ & 696 followed for 18 months (France) & 41 & 36.1 & 97 & $\begin{array}{l}\text { Orlistat } 120 \text { mg three times daily } \\
(n=346) ; \text { placebo }(n=350)\end{array}$ & $35 / 43$ & $\begin{array}{l}20 \% \text { energy reduced diet, } \\
\text { increased by } 10 \% \text { if weight } \\
\text { stable; food diary }\end{array}$ \\
\hline Lindgarde $^{\text {w11 }}$ & $\begin{array}{l}376 \text { with type } 2 \text { diabetes, hypertension } \\
\text { or dyslipidaemia, } 1 \text { year follow-up } \\
\text { (Sweden) }\end{array}$ & 53 & 33.2 & 96 & $\begin{array}{l}\text { Orlistat } 120 \text { mg three times daily } \\
(n=190) ; \text { placebo }(n=186)\end{array}$ & $16 / 12$ & $\begin{array}{l}2.5-3.8 \mathrm{MJ} / \text { day deficit diet; } \\
\text { exercise; educational package }\end{array}$ \\
\hline Miles $^{\mathrm{w} 12}$ & $\begin{array}{l}156 \text { with type } 2 \text { diabetes receiving oral } \\
\text { hypoglycaemics, } 1 \text { year follow-up (US } \\
\text { and Canada) }\end{array}$ & 53 & 35.4 & 102 & $\begin{array}{l}\text { Orlistat } 120 \mathrm{mg} \text { three times daily } \\
(n=255) ; \text { placebo }(n=261)\end{array}$ & $35 / 44$ & $\begin{array}{l}\text { 2.5-3.3 MJ/day deficit diet; } \\
\text { exercise }\end{array}$ \\
\hline Rossner $^{\text {w13 }}$ & $\begin{array}{l}729 \text { followed for } 1 \text { year and a second } \\
\text { weight maintenance year (Europe) }\end{array}$ & 44 & 35.1 & 98 & $\begin{array}{l}\text { Orlistat } 120 \mathrm{mg} \text { three times daily } \\
(n=244) ; \text { placebo }(n=243)\end{array}$ & $26 / 35$ & $\begin{array}{l}2.5 \mathrm{MJ} / \text { day deficit diet; food } \\
\text { diary }\end{array}$ \\
\hline Sjostrom ${ }^{\text {w14 }}$ & $\begin{array}{l}688 \text { followed for } 1 \text { year and a second } \\
\text { weight maintenance year (Europe) }\end{array}$ & 45 & 36.1 & 100 & $\begin{array}{l}\text { Orlistat } 120 \text { mg three times daily } \\
(n=345) ; \text { placebo }(n=343)\end{array}$ & $17 / 20$ & 2.5-3.8 MJ/day deficit diet \\
\hline Swinburnw15 & $\begin{array}{l}339 \text { with } \geq 1 \text { cardiovascular risk factor, } \\
1 \text { year follow-up (Australia and New } \\
\text { Zealand) }\end{array}$ & 52 & 37.8 & 87 & $\begin{array}{l}\text { Orlistat } 120 \text { mg three times daily } \\
(n=170) ; \text { placebo }(n=169)\end{array}$ & $22 / 19$ & Diet and exercise counselling \\
\hline $\mathrm{XENDOS}^{\mathrm{w} 16}$ & $\begin{array}{l}3305 \text { patients ( } 21 \% \text { with impaired } \\
\text { glucose tolerance), } 4 \text { year follow-up } \\
\text { (Sweden) }\end{array}$ & 43 & 37.3 & 111 & $\begin{array}{l}\text { Orlistat } 120 \text { mg three times daily } \\
(n=1650) ; \text { placebo }(n=1655)\end{array}$ & $48 / 66$ & $\begin{array}{l}\text { 3.3 MJ/day deficit diet; } \\
\text { exercise counselling }\end{array}$ \\
\hline
\end{tabular}


reported in a last observation carried forward fashion (in which the last observation on record was used as a surrogate for the final value). The meta-analysis used a random effects model with RevMan 4.2.9.

We used $\chi^{2}$ to assess heterogeneity and the Higgins $\mathrm{I}^{2}$ statistic to determine the percentage of total variation across studies due to heterogeneity. ${ }^{11}$ If the $\mathrm{I}^{2}$ statistic showed substantial heterogeneity (over 50\%), we did not quantitatively pool results unless the observed statistical heterogeneity was judged to be of little clinical relevance (that is, studies consistently reporting results in the same direction with clinically insignificant differences between studies).

We visually examined funnel plots to determine publication bias if there were over 10 studies for a given drug.

\section{RESULTS}

Search results

Figure 1 summarises the results of the search (fig 1). We identified 27 potentially relevant trials, and five orlistat, five sibutramine, and four rimonabant studies met final inclusion criteria. These were added to the 11 orlistat and five sibutramine trials previously identified. ${ }^{8}$ Cohen's $\kappa$ coefficient for inter-rater agreement measured 0.95 for trial selection and 0.85 for study quality.

\section{Description of studies}

Thirty double blind placebo controlled randomised controlled trials were included in the final review: 16 orlistat ( $\mathrm{n}=10631$ participants), 10 sibutramine $(\mathrm{n}=2623), \quad$ and four rimonabant $(\mathrm{n}=6635)$ (tables 1-3). ${ }^{\text {w1-30 }}$ Twenty seven of these studies received funding from the drug manufacturer.

Nine orlistat studies limited enrolment to higher risk populations: four recruited patients with type 2 diabetes $^{\text {w2 w8 } w 9 w 12}$ and five enrolled obese patients with at least one cardiovascular risk factor (hypertension, dyslipidaemia, diabetes, or impaired glucose

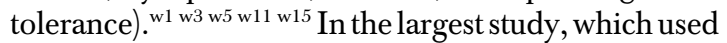
orlistat (Xenical in the prevention of diabetes in obese subjects, XENDOS), 21\% of patients had impaired glucose tolerance. ${ }^{\text {w16 }}$

Two sibutramine studies limited enrolment to patients with hypertension with controlled blood pressure $^{\mathrm{w} 22 \mathrm{w} 23}$ and three enrolled patients with type 2 diabetes. $^{\text {w20 w24 w25 }}$

One rimonabant study enrolled patients with dyslipidaemia (rimonabant in obesity (RIO)-lipids), ${ }^{\text {w29 }}$ one enrolled patients with diabetes (rimonabant in obesity-diabetes), ${ }^{\text {w27 }}$ and the other two commonly included patients with dyslipidaemia or hypertension (rimonabant in obesity-Europe; rimonabant in obesity-North America). ${ }^{\text {w28 w30 }}$

\section{Interventions}

Twenty seven studies (16 orlistat, seven sibutramine, and four rimonabant) were weight loss trials, in which drug treatment was used in conjunction with a weight loss diet for one to four years. Of these, one rimonabant and four orlistat studies also contained a second weight maintenance year. ${ }^{\mathrm{w} 4 \mathrm{w} 7 \mathrm{w} 13 \mathrm{w} 14 \mathrm{w} 30}$ The three remaining sibutramine trials were weight maintenance studies, in which randomisation was performed after a one to

\begin{tabular}{|c|c|c|c|c|c|c|c|}
\hline & Study population & $\begin{array}{l}\text { Mean age } \\
\text { (years) }\end{array}$ & $\begin{array}{c}\text { Mean } \\
\text { BMI }\end{array}$ & $\begin{array}{c}\text { Mean } \\
\text { weight (kg) }\end{array}$ & Comparison & $\begin{array}{c}\text { Attrition (\% } \\
\text { drug/placebo) }\end{array}$ & Cointerventions \\
\hline Apfelbaum $^{\text {w17 }}$ & $\begin{array}{l}205 \text { underwent } 4 \text { week very low calorie diet, } \\
\text { those who lost } \geq 6 \mathrm{~kg} \text { ( } \mathrm{n}=160 \text { ) randomised to } \\
\text { treatment or placebo, } 1 \text { year follow-up (France) }\end{array}$ & 38 & 35.5 & 104 & $\begin{array}{l}\text { Sibutramine } 10 \text { mg daily }(n=352) \\
\text { placebo }(n=78)\end{array}$ & $34 / 42$ & Diet counselling \\
\hline Hauner $^{\text {w18 }}$ & $\begin{array}{l}362 \text { from primary care, } 54 \text { week follow-up } \\
\text { (Germany) }\end{array}$ & 43 & 35.3 & 100 & $\begin{array}{l}\text { Sibutramine } 15 \text { mg daily }(n=180) \text {; } \\
\text { placebo }(n=182)\end{array}$ & $40 / 48$ & $\begin{array}{l}\text { 2.1-4.2 MJ/day deficit } \\
\text { diet; exercise; food diary }\end{array}$ \\
\hline James $^{\text {w19 }}$ & $\begin{array}{l}605 \text { receiving sibutramine } 5 \mathrm{mg} \text { daily and diet } \\
\text { for } 6 \text { months, those who lost } 5 \% \text { of weight } \\
\text { ( } \mathrm{n}=467 \text { ) randomised to treatment or placebo, } \\
18 \text { month follow-up (Europe) }\end{array}$ & 41 & 36.7 & 102 & $\begin{array}{l}\text { Sibutramine } 10-20 \text { mg daily } \\
(n=352) ; \text { placebo }(n=115)\end{array}$ & $15 / 28$ & $\begin{array}{l}2.5 \mathrm{MJ} / \text { day deficit diet; } \\
\text { exercise counselling }\end{array}$ \\
\hline Kaukuaw20 & $\begin{array}{l}236 \text { with type } 2 \text { diabetes, } 1 \text { year follow-up } \\
\text { (Finland) }\end{array}$ & 53 & 35.7 & 99 & $\begin{array}{l}\text { Sibutramine } 15 \text { mg daily }(n=114) \text {; } \\
\text { placebo }(n=122)\end{array}$ & $11 / 11$ & $2.9 \mathrm{MJ} /$ day deficit diet \\
\hline $\begin{array}{l}\text { Mathus- } \\
\text { Vliegen }^{\text {w21 }}\end{array}$ & $\begin{array}{l}221 \text { receiving very low calorie diet for } 3 \text { months. } \\
\text { Those who lost } \geq 10 \% \text { of weight }(n=189) \\
\text { randomised to treatment or placebo, } \\
18 \text { months follow-up (Dutch) }\end{array}$ & 43 & 36.6 & 105 & $\begin{array}{l}\text { Sibutramine } 10-15 \text { mg daily }(n=94) ; \\
\text { placebo }(n=95)\end{array}$ & $35 / 39$ & $2.5 \mathrm{MJ} /$ day deficit diet \\
\hline $\begin{array}{l}\text { McMahon } \\
2000^{\text {w22 }}\end{array}$ & $\begin{array}{l}224 \text { with controlled hypertension, } 1 \text { year follow- } \\
\text { up ( } 36 \% \text { African-American; US) }\end{array}$ & 53 & 34.3 & 97 & $\begin{array}{l}\text { Sibutramine } 20 \text { mg daily }(n=170) \text {; } \\
\text { placebo }(n=169)\end{array}$ & $22 / 19$ & Diet counselling \\
\hline $\begin{array}{l}\text { McMahon } \\
2002^{\text {w23 }}\end{array}$ & $\begin{array}{l}220 \text { with controlled hypertension. } 1 \text { year follow- } \\
\text { up (US) }\end{array}$ & 51 & 33.9 & 98 & $\begin{array}{l}\text { Sibutramine } 20 \text { mg daily }(n=146) ; \\
\text { placebo }(n=74)\end{array}$ & $42 / 51$ & Diet counselling \\
\hline McNultyw24 & $\begin{array}{l}194 \text { with type } 2 \text { diabetes, } 1 \text { year follow-up (UK, } \\
\text { Canada, France, Belgium) }\end{array}$ & 49 & 36.6 & 103 & $\begin{array}{l}\text { Sibutramine } 15 \text { mg daily }(n=68) ; \\
\text { placebo }(n=62)\end{array}$ & $28 / 21$ & Diet counselling \\
\hline $\begin{array}{l}\text { Sanchez- } \\
\text { Reyes }^{\text {w25 }}\end{array}$ & $\begin{array}{l}86 \text { with type } 2 \text { diabetes treated with } \\
\text { sulfonylureas, } 1 \text { year follow-up (Mexico) }\end{array}$ & 44 & 35.1 & 98 & $\begin{array}{l}\text { Sibutramine } 10 \text { mg daily }(n=44) \text {; } \\
\text { placebo }(n=42)\end{array}$ & $45 / 45$ & $\begin{array}{l}\text { Diet and exercise } \\
\text { counselling }\end{array}$ \\
\hline Smith $^{\text {w26 }}$ & 485 from primary care, 1 year follow-up (UK) & 42 & 32.7 & 87 & $\begin{array}{l}\text { Sibutramine } 10 \text { mg daily }(n=161) ; \\
\text { sibutramine } 15 \text { mg daily }(n=161) ; \\
\text { placebo }(n=161)\end{array}$ & $42 / 49 / 51$ & Diet counselling \\
\hline
\end{tabular}


Citations from search (Dec 2002 to Dec 2006) (n=1394)

Citations excluded (wrong topic, not randomised controlled trial, follow-up period $<1$ year) $(n=1367)$

Potentially relevant randomised controlled trials identified and screened to be included in systematic review $(n=27)$

Randomised controlled trials excluded from
systematic review $(n=13)$ :
Previously reported data $(n=4)$
Wrong subject matter $(n=1)$
Open label trial $(n=2)$
Age $<18$ years $(n=2)$
Follow-up period $<1$ year $(n=3)$
Uncertain blinding status $(n=1)$

Fig 1| Results of search for relevant studies

six month induction phase with reduced energy intake. ${ }^{\mathrm{w} 17 \mathrm{w} 19 \mathrm{w} 21}$ A standardised, low fat, low energy diet and encouragement to exercise were the main cointerventions in most weight loss studies.

\section{Inclusion and exclusion criteria}

Trials generally enrolled selected patients with few comorbidities who were able to adhere to a run-in phase protocol. Patients had similar demographic profiles across trials of all three drugs: about two thirds to three quarters of participants were women, about $90 \%$ were white, mean age was $45-50$ years, mean weight was about $100 \mathrm{~kg}$, and mean body mass index was 35-36 (class 2 obesity). ${ }^{7}$

In most studies exclusion criteria were obesity of endocrine origin, uncontrolled hypertension, treatment with drugs affecting body weight, pregnancy or lactation, relevant psychiatric or medical illness, previous bariatric surgery, and considerable weight loss before screening.

\section{Methodological quality}

Studies were all of similar quality, ${ }^{7}$ and the most important methodological limitation was high attrition rates, which averaged $30 \%$ for orlistat studies and $40 \%$ for sibutramine and rimonabant studies. The most common reasons for premature withdrawal were refusal of treatment, loss to follow-up, and adverse effects. Most studies did not describe the randomisation process or comment on allocation concealment. No study specifically mentioned blinding of outcome assessors. All studies reported eligibility criteria, and cointerventions were similar in intervention and control arms. Although all included studies described using an intention to treat analysis, the validity of this approach was compromised by the high attrition rates. Because there was little variation in quality and weight loss results, we did not perform sensitivity analyses according to study quality.

Secondary end points were inconsistently reported, sometimes in only a subgroup of patients, or were not reported in an extractable manner. Our analysis includes only those data that were extractable from a given study.

\section{Heterogeneity}

Significant heterogeneity $\left(\mathrm{I}^{2} \geq 50 \%\right)$ was present in several anthropometric outcomes but was not judged to be clinically relevant. Substantial heterogeneity $\left(\mathrm{I}^{2}>80 \%\right)$ was also present when we pooled the effects of orlistat and rimonabant on glycaemic control. For orlistat, this heterogeneity was attenuated and did not seem clinically relevant when we limited pooling to patients with diabetes alone. For rimonabant, we have reported glycaemic control results only for the single trial involving patients with type 2 diabetes.

\section{Outcomes}

The number of patients included in a given endpoint analysis may be lower that the overall total number of patients studied because we extracted data only for the highest dose of a given drug and the end point may not have been reported at all or not reported in an

\begin{tabular}{|c|c|c|c|c|c|c|c|}
\hline & Study population & $\begin{array}{l}\text { Mean age } \\
\text { (years) }\end{array}$ & Mean BMI & $\begin{array}{l}\text { Mean weight } \\
(\mathrm{kg})\end{array}$ & Comparison & $\begin{array}{c}\text { Attrition } \\
\text { (\% drug/placebo) }\end{array}$ & Cointerventions \\
\hline $\begin{array}{l}\text { RIO- } \\
\text { Diabe- } \\
\text { tes }^{\text {w27 }}\end{array}$ & $\begin{array}{l}1047 \text { with type } 2 \text { diabetes receiving } \\
\text { oral hypoglycaemics, } 1 \text { year follow-up } \\
\text { (11 countries) }\end{array}$ & 56 & 34.2 & 98 & $\begin{array}{l}\text { Rimonabant } 5 \text { mg daily }(n=358) ; \\
\text { rimonabant } 20 \text { mg daily }(n=339) \text {; } \\
\text { placebo }(n=348)\end{array}$ & $35 / 32 / 34$ & $\begin{array}{l}2.5 \mathrm{MJ} / \text { day deficit diet; } \\
\text { exercise counselling }\end{array}$ \\
\hline $\begin{array}{l}\text { RIO- } \\
\text { Europe }^{\text {w30 }}\end{array}$ & $\begin{array}{l}1507 \text { with hypertension ( } 41 \% \text { ) or } \\
\text { dyslipidaemia (61\%), } 1 \text { yearfollow-up } \\
\text { (Europe and US) }\end{array}$ & 45 & 36 & 101 & $\begin{array}{l}\text { Rimonabant } 5 \text { mg daily }(n=603) ; \\
\text { rimonabant } 20 \text { mg daily }(n=599) \text {; } \\
\text { placebo }(n=305)\end{array}$ & $39 / 37 / 42$ & $\begin{array}{l}2.5 \mathrm{MJ} / \text { day deficit diet; } \\
\text { exercise counselling }\end{array}$ \\
\hline $\begin{array}{l}\text { RIO- } \\
\text { Lipidsw29 }^{\text {w29 }}\end{array}$ & $\begin{array}{l}1036 \text { patients with untreated } \\
\text { dyslipidaemia, } 1 \text { year follow-up } \\
\text { (Europe and North America) }\end{array}$ & 48 & 34 & 98 & $\begin{array}{l}\text { Rimonabant } 5 \text { mg daily }(n=346) ; \\
\text { rimonabant } 20 \text { mg daily }(n=345) \text {; } \\
\text { placebo }(n=342)\end{array}$ & $36 / 40 / 37$ & $2.5 \mathrm{MJ} /$ day deficit diet \\
\hline $\begin{array}{l}\text { RIO-North } \\
\text { America }^{\text {w28 }}\end{array}$ & $\begin{array}{l}3045 \text { patients with hypertension } \\
(30 \%) \text { or dyslipidaemia (63\%). } 2 \text { year } \\
\text { follow-up (Europe and US) }\end{array}$ & 45 & 37.6 & 104 & $\begin{array}{l}\text { Rimonabant } 5 \text { mg daily }(n=1216) ; \\
\text { rimonabant } 20 \text { mg daily }(n=1222) \text {; } \\
\text { placebo }(n=607)\end{array}$ & 49/45/49 & $\begin{array}{l}2.5 \mathrm{MJ} / \text { day deficit diet; } \\
\text { exercise counselling }\end{array}$ \\
\hline
\end{tabular}




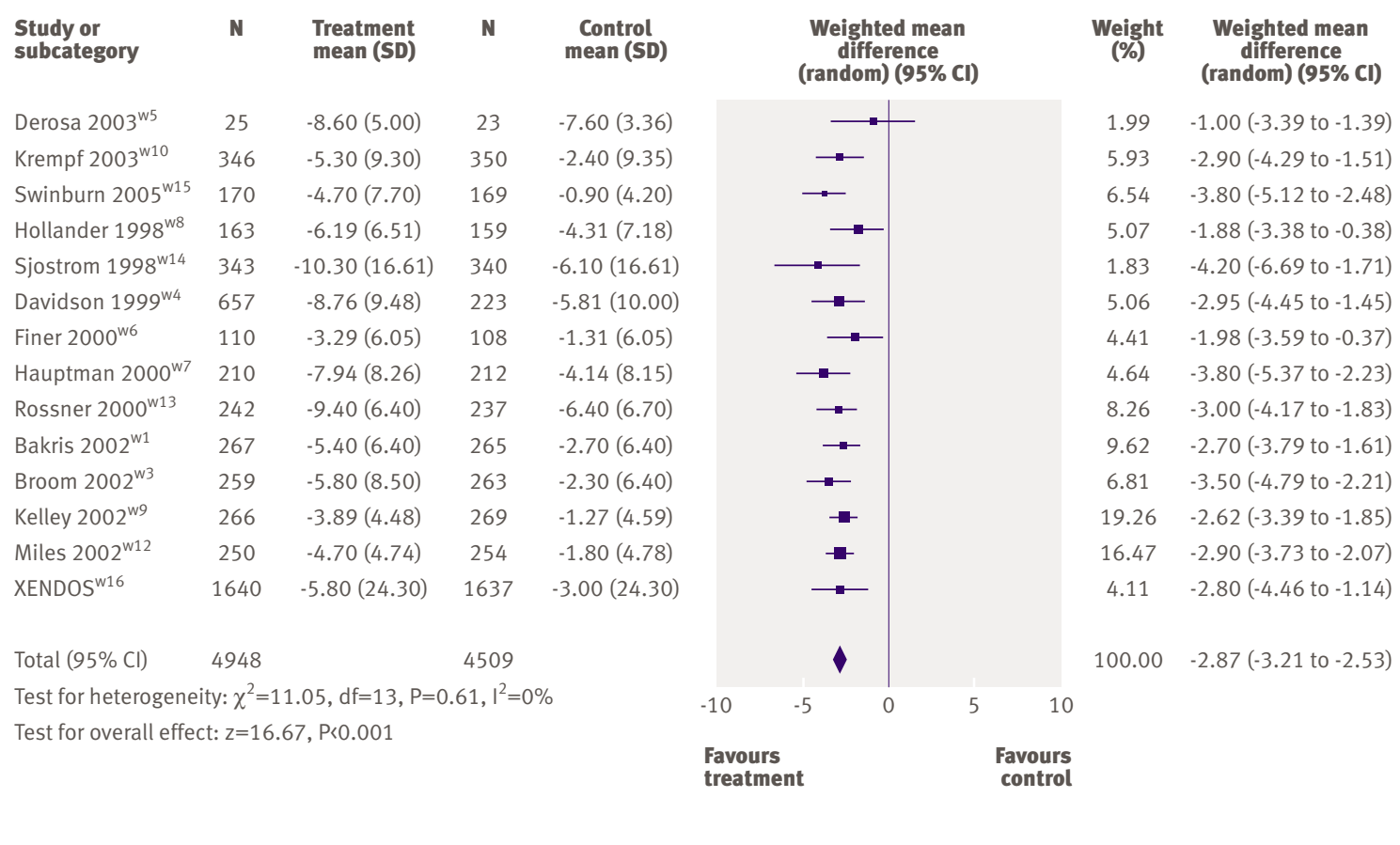

Fig 2 | Placebo subtracted weight reduction (kg) with orlistat

extractable manner. None of the trials reported total mortality, cardiovascular morbidity, and cardiovascular mortality as end points.

Orlistat

Body weight - Orlistat reduced weight by $2.9 \mathrm{~kg}(95 \%$ confidence interval $2.5 \mathrm{~kg}$ to $3.2 \mathrm{~kg} ; 15$ studies; fig 2) or $2.9 \%$ (2.5\% to $3.4 \% ; 13$ studies) more than placebo and increased the absolute percentage of participants achieving $5 \%$ and $10 \%$ weight loss thresholds by $21 \%$ $(54 \%$ v $33 \% ; 18 \%$ to $24 \% ; 14$ studies) and $12 \%$ (26\% v $14 \% ; 9 \%$ to $14 \% ; 13$ studies), respectively (table 4). Placebo subtracted weight loss was $2.6 \%$ (2.1\% to $3.2 \%$; five studies) or $2.3 \mathrm{~kg}$ (1.6 kg to $3.0 \mathrm{~kg}$; four studies) in patients with diabetes receiving orlistat. In the four studies with a second year of weight

\begin{tabular}{|c|c|c|}
\hline Outcome & $\begin{array}{l}\text { No of studies } \\
\text { (sample size) }\end{array}$ & $\begin{array}{l}\text { Weighted mean difference or risk difference } \\
\text { (active minus placebo) }(95 \% \mathrm{Cl})\end{array}$ \\
\hline Change in weight (kg) & $15(9833)$ & $-2.87(-3.21$ to -2.53$)$ \\
\hline Change in weight (\%) & $13(6196)$ & $-2.93(-3.35$ to -2.50$)$ \\
\hline $5 \%$ responders (absolute \% difference) & 14 (9389) & $0.21^{\star}(0.18$ to 0.24$)$ \\
\hline $10 \%$ responders (absolute \% difference) & $13(8857)$ & $0.12^{\star}(0.09$ to 0.14$)$ \\
\hline \multicolumn{3}{|l|}{ Change in: } \\
\hline Waist circumference (cm) & $9(4631)$ & $-2.06(-2.86$ to -1.26$)$ \\
\hline BMI & $3(1276)$ & $-1.05(-1.40$ to -0.71$)$ \\
\hline Systolic blood pressure (mm Hg) & $13(6965)$ & $-1.52(-2.19$ to -0.86$)$ \\
\hline Diastolic blood pressure (mm Hg) & $12(8322)$ & $-1.38(-2.03$ to -0.74$)$ \\
\hline Total cholesterol (mmol/l) & $13(5206)$ & $-0.32(-0.37$ to -0.28$)$ \\
\hline Low density lipoprotein cholesterol (mmol/l) & $13(5206)$ & $-0.26(-0.30$ to -0.22$)$ \\
\hline High density lipoprotein cholesterol (mmol/l) & $11(4152)$ & $-0.03(-0.04$ to -0.02$)$ \\
\hline Triglycerides (mmol/l) & $11(4456)$ & $-0.03(-0.12$ to 0.07$)$ \\
\hline Weight in those with diabetes (\%) & $5(1678)$ & $-2.61(-3.06$ to -2.17$)$ \\
\hline Weight in those with diabetes $(\mathrm{kg})$ & $4(1737)$ & $-2.30(-3.00$ to -1.60$)$ \\
\hline Fasting glucose in those with diabetes (mmol/l) & $5(1678)$ & $-1.03(-1.49$ to -0.57$)$ \\
\hline Haemoglobin $\mathrm{A}_{1 \mathrm{C}}$ in those with diabetes (\%) & $5(1678)$ & $-0.38^{\star}(-0.59$ to -0.18$)$ \\
\hline Overall gastrointestinal adverse events (\%) & $14(8938)$ & $0.24^{\star}(0.20$ to 0.29$)$ \\
\hline Faecal incontinence (\%) & $4(1636)$ & $0.06^{*}(0.05$ to 0.08$)$ \\
\hline Discontinuation because of gastrointestinal side effects (\%) & $12(5994)$ & $0.02(0.01$ to 0.03$)$ \\
\hline
\end{tabular}


maintenance, both orlistat and placebo arms showed similar amounts of weight regain, though the weight differential observed after the weight loss phase was preserved. ${ }^{\mathrm{w} 4 \mathrm{w} 7 \mathrm{w} 13 \mathrm{w} 14}$

Secondary end points - Orlistat reduced the incidence of type 2 diabetes from $9.0 \%$ to $6.2 \%$ (hazard ratio 0.63 ; $95 \%$ confidence interval 0.46 to 0.86 ) in one four year trial. ${ }^{\text {w16 }}$ This benefit was observed primarily in patients with impaired glucose tolerance at baseline. Compared with placebo, orlistat also significantly reduced waist circumference, body mass index, systolic blood pressure, diastolic blood pressure, fasting glucose and haemoglobin $\mathrm{A}_{1 \mathrm{C}}$ concentrations in patients with diabetes, and total cholesterol, low density lipoprotein cholesterol, and high density lipoprotein cholesterol concentrations (table 4). Fasting glucose concentrations were significantly reduced $(\mathrm{P}<0.05)$ in four of six studies that did not exclusively enrol patients with type 2 diabetes. There was no significant difference between orlistat and placebo in triglyceride concentrations or the change in Framingham cardiovascular risk score. ${ }^{\mathrm{w} 15}$

Adverse effects - Patients receiving orlistat were more likely to experience gastrointestinal adverse events and to discontinue because of this (table 4). The most commonly reported gastrointestinal events were fatty/oily stool, faecal urgency, and oily spotting, each occurring at frequency rates of $15 \%$ to $30 \%$ in most studies.
Although concentrations of fat soluble vitamins were reportedly lowered, no study reported clinically relevant vitamin deficiency. Patients receiving orlistat were routinely advised to take daily multivitamins.

\section{Sibutramine}

Weight loss_Patients receiving sibutramine lost $4.2 \mathrm{~kg}$ (3.6 kg to $4.7 \mathrm{~kg}$; eight studies; fig 3 ) or $4.3 \%$ (3.7\% to $5.0 \% ; 10$ studies) more weight than those taking placebo. In addition, sibutramine treatment increased the absolute percentage of $5 \%$ and $10 \%$ responders by $32 \%(55 \%$ v $27 \% ; 27 \%$ to $37 \%$; seven studies) and $18 \%$ (28\% v $10 \% ; 11 \%$ to $25 \%$; seven studies), respectively (table 5). Placebo subtracted weight losses in patients with diabetes were $5.0 \%$ (3.8\% to $6.2 \%)$ or $4.9 \mathrm{~kg}$ ( $3.6 \mathrm{~kg}$ to $6.2 \mathrm{~kg}$ ). About 10-30\% more sibutramine patients achieved successful weight maintenance compared with placebo (successful weight maintenance defined as maintaining $80-100 \%$ of the initial weight loss). This was significant $(\mathrm{P}<0.05)$ in all three studies but we did not combine data because of differing definitions of weight maintenance between studies. ${ }^{\text {w17 w19 w21 }}$

Secondary end points - Treatment with sibutramine significantly reduced body mass index, waist circumference, and triglyceride concentrations and increased concentrations of high density lipoprotein cholesterol (table 5). Change in glycaemic variables and concentrations of low density lipoprotein

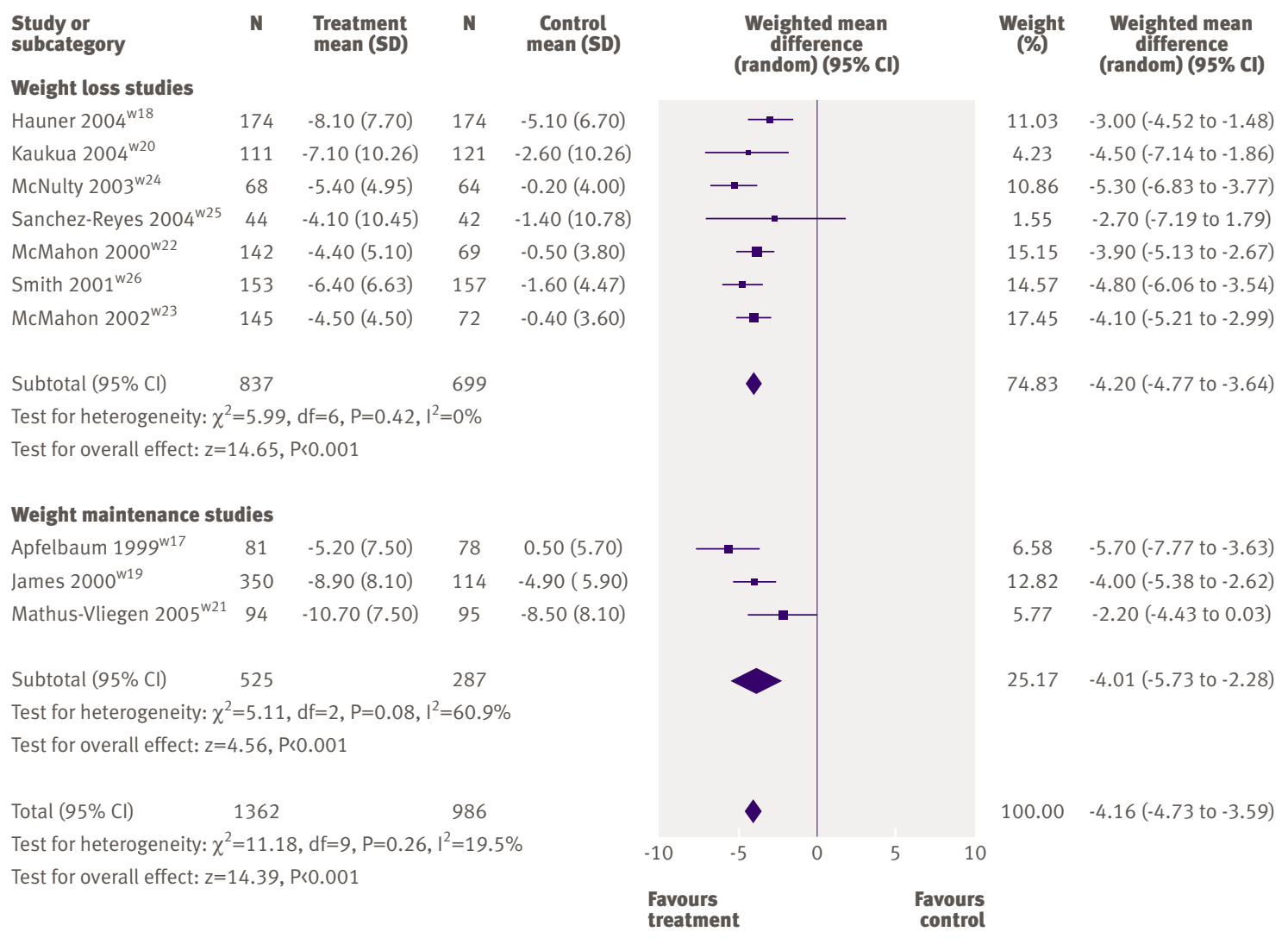




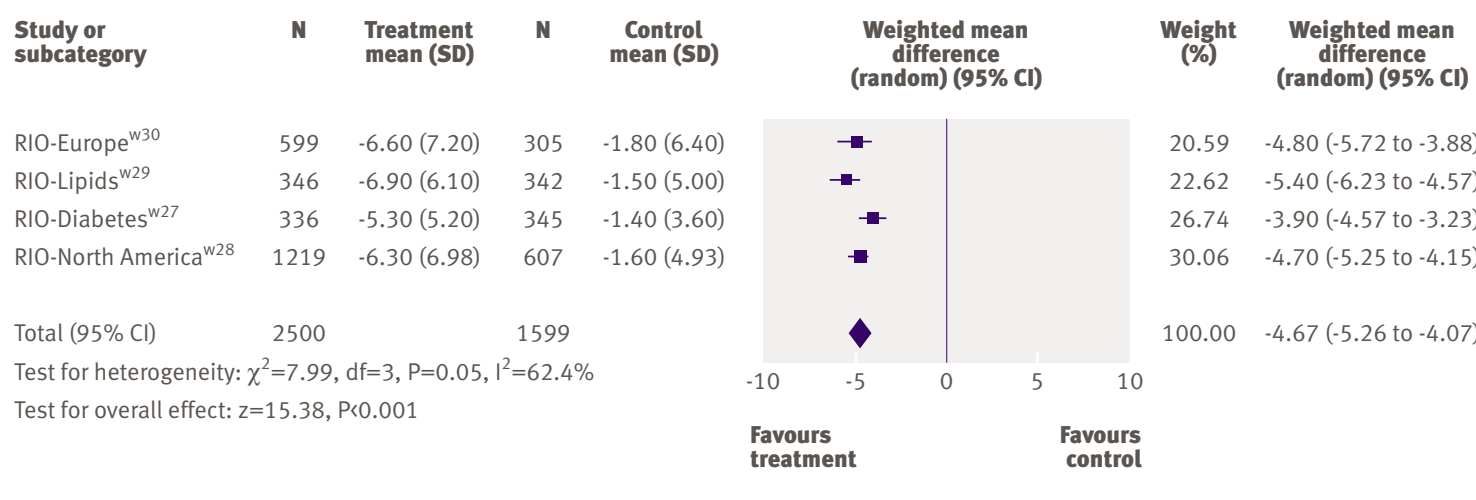

Fig 4 | Placebo subtracted weight reduction $(\mathrm{kg})$ with rimonabant

cholesterol and total cholesterol were inconsistently reported and, when reported, were not significantly different from values in the placebo group in any study.

Adverse effects - Compared with placebo, sibutramine increased systolic blood pressure by $1.7 \mathrm{~mm} \mathrm{Hg}$ (0.1 mm Hg to $3.3 \mathrm{~mm} \mathrm{Hg}$; seven studies), diastolic blood pressure by $2.4 \mathrm{~mm} \mathrm{Hg}(1.5 \mathrm{~mm} \mathrm{Hg}$ to $3.3 \mathrm{~mm}$ $\mathrm{Hg}$; seven studies), and pulse rate by 4.5 beats $/ \mathrm{min}$ (3.5 beats/min to $5.6 \mathrm{beats} / \mathrm{min}$; seven studies) (table 5). Insomnia, nausea, dry mouth, and constipation were more common in patients receiving sibutramine, occurring at frequency rates of $7-20 \%$.

\section{Rimonabant}

Weight loss_Patients receiving rimonabant lost $4.7 \mathrm{~kg}$ (4.1 kg to $5.3 \mathrm{~kg}$; four studies; fig 4) more weight than those taking placebo. The average weight loss was 3.9 $\mathrm{kg}$ ( $3.2 \mathrm{~kg}$ to $4.6 \mathrm{~kg}$ ) in the rimonabant in obesitydiabetes trial. ${ }^{\text {27 }}$ Rimonabant treatment also significantly increased the placebo subtracted absolute percentage of $5 \%$ and $10 \%$ responders by $33 \%(51 \%$ $v 18 \% ; 29 \%$ to $37 \%$; four studies) and $19 \%(26 \%$ v $7 \%$; $15 \%$ to $23 \%$; seven studies), respectively (table 6 ). During the weight maintenance phase of the

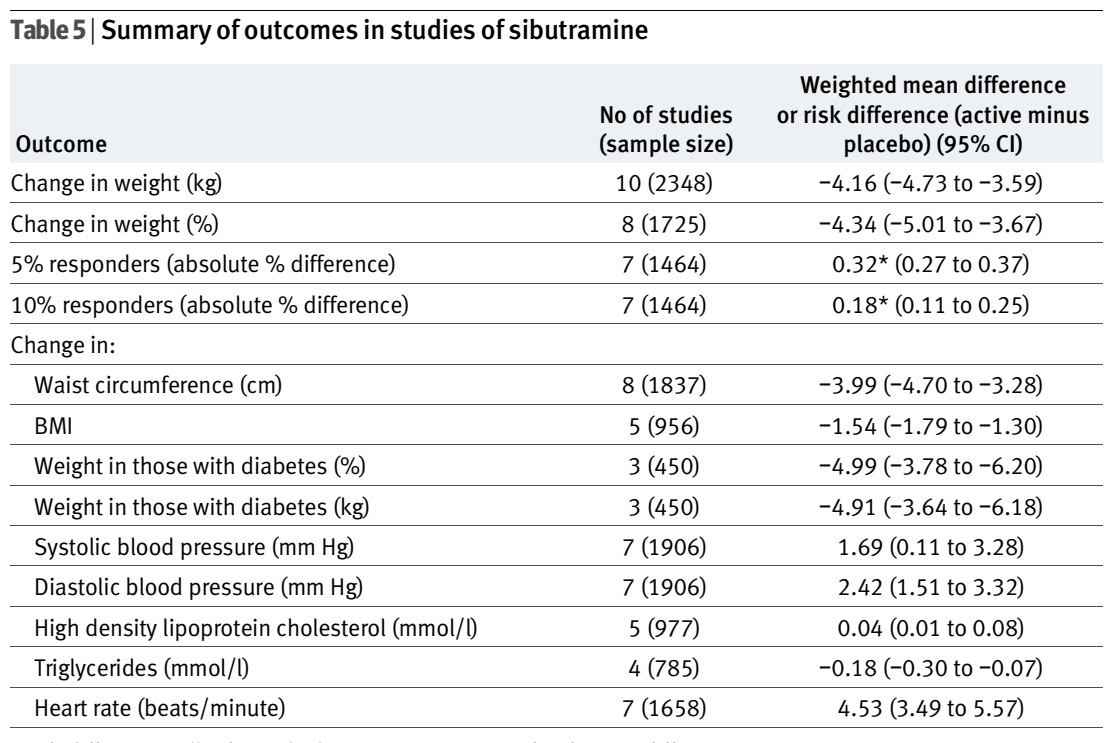

*Risk difference. All other calculations represent weighted mean difference. rimonabant in obesity-North America study, patients treated with rimonabant maintained the weight differential observed in the weight loss phase of the study. ${ }^{\text {w30 }}$

Secondary end points-Rimonabant significantly reduced placebo subtracted waist circumference, systolic blood pressure, diastolic blood pressure, and triglyceride concentrations and increased high density lipoprotein cholesterol concentrations (table 6). Fasting glucose and haemoglobin $\mathrm{A}_{1 \mathrm{C}}$ concentrations were significantly reduced in the rimonabant in obesity-diabetes $s$ sudy $^{\text {w27 }}$ but not in the other rimonabant in obesity studies (table 6). Low density lipoprotein cholesterol and total cholesterol concentrations were not significantly reduced compared with placebo.

Adverse effects - The most worrying adverse effect was an increased incidence of psychiatric disorders (depression, anxiety, irritability, aggression), which occurred in $6 \%$ of patients receiving rimonabant and was $3 \%$ (2\% to $5 \%$; four studies) more likely in patients receiving rimonabant compared with placebo (table 6).

\section{DISCUSSION}

Our meta-analysis of one to four year randomised controlled trials of orlistat, sibutramine, and rimonabant in adults showed that each drug results in average placebo subtracted weight reductions of less than $5 \mathrm{~kg}$. We found no data on the effect of these agents on mortality or cardiovascular morbidity. Weight maintenance studies for each drug reported similar amounts of weight regained in active and placebo arms, such that the original weight differential between groups was maintained. We found differing effects on secondary end points and adverse effect profiles. These updated results are consistent with the results of previous reviews ${ }^{812-15}$ but more precisely define the long term effects of current agents on weight and secondary end points and describe each drug's unique adverse effect profile.

\section{Limitations}

There are several limitations to this meta-analysis. Firstly, all studies showed a positive effect of treatment on weight loss, which raises the possibility of publication bias. A funnel plot of orlistat studies 


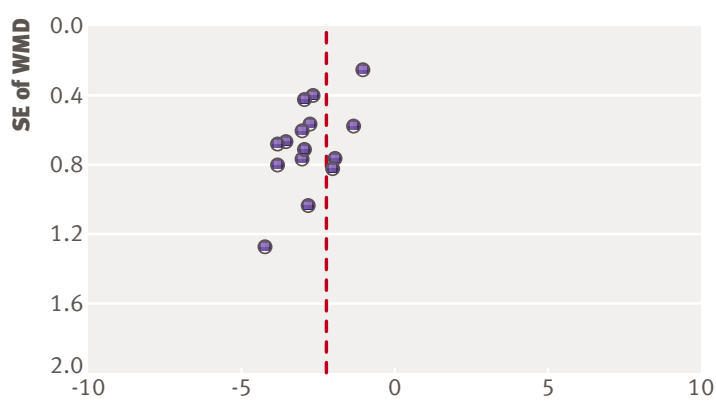

Weighted mean difference (kg)

Fig 5 | Funnel plot of orlistat studies for weight loss

indicates that we might have underestimated the impact of all types of small studies (positive, negative, or neutral) in this meta-analysis (fig 5). ${ }^{7}$ There were too few sibutramine and rimonabant studies to warrant generation of funnel plots. Nearly all trials were funded by pharmaceutical companies, which may increase the likelihood of positive results. ${ }^{16}$ Secondly, most patients studied were non-elderly and white and extrapolation to other populations should be made with caution. Thirdly, we found statistical heterogeneity when we quantitatively pooled several outcomes. This was addressed by using a random effects meta-analysis and by not combining outcomes when the heterogeneity was thought to be clinically relevant. As we did not have access to data on individual patients, we could not perform meta-regression analysis to further investigate the cause of the observed heterogeneity. Differences in populations of patients, cointerventions, trial duration, and drug dose were probably all contributing factors. Fourthly, our analysis includes only those data that were extractable from a given study and studies may have reported full results only for end points that significantly differed from placebo.

\section{Synthesis of findings}

Previous studies have shown that people with diabetes find it more difficult to lose weight, possibly because of the underlying disease state or because medications used to treat diabetes tend to increase weight. ${ }^{217} \mathrm{We}$ found that studies enrolling patients with diabetes reported slightly smaller amounts of weight loss with orlistat and rimonabant, a finding not seen with sibutramine. Despite this finding, both orlistat and rimonabant improved glycaemic variables in patients with diabetes, whereas sibutramine did not. The underlying reasons for this and the clinical relevance are unclear. One potential contributor to improved glycaemic control with rimonabant is an increase in adiponectin. ${ }^{\text {w29 }}$ Further data are needed, ideally from head to head clinical trials of all three agents, before more definitive conclusions can be made.

Even though studies preselected patients for their ability to adhere to and to tolerate treatment, attrition rates were high, compromising the internal validity of many studies. It is difficult to compensate for such high attrition rates by using any form of analysis. A recent study using Canadian provincial administrative data reported persistence rates with orlistat and sibutramine of less than $10 \%$ at one year and less than $2 \%$ at two years. ${ }^{18}$ Lack of adherence to treatment seems to be a major factor limiting the efficacy and effectiveness of anti-obesity drugs.

The observed increase in blood pressure and heart rate with sibutramine are of potential concern, and blood pressure should be monitored during treatment. The increased incidence of mood disorders with rimonabant indicates careful surveillance, particularly

\begin{tabular}{|c|c|c|}
\hline Outcome & $\begin{array}{l}\text { No of studies } \\
\text { (sample size) }\end{array}$ & $\begin{array}{l}\text { Weighted mean difference or risk difference } \\
\text { (active minus placebo) }(95 \% \mathrm{Cl})\end{array}$ \\
\hline Change in weight (kg) & $4(4099)$ & $-4.67(-5.26$ to -4.07$)$ \\
\hline $5 \%$ responders (absolute \% difference) & $4(4099)$ & $0.33^{\star}(0.29 .0 .37)$ \\
\hline $10 \%$ responders (absolute $\%$ difference) & $4(4099)$ & $0.19^{\star}(0.15$ to 0.23$)$ \\
\hline \multicolumn{3}{|l|}{ Change in: } \\
\hline Waist circumference $(\mathrm{cm})$ & $4(4098)$ & $-3.89(-4.47$ to -3.30$)$ \\
\hline Systolic blood pressure $(\mathrm{mm} \mathrm{Hg})$ & $3(2273)$ & $-1.78(-2.81$ to -0.76$)$ \\
\hline Diastolic blood pressure $(\mathrm{mm} \mathrm{Hg})$ & $3(2273)$ & $-1.23(-1.93$ to -0.54$)$ \\
\hline Total cholesterol (mmol/l) & $3(2223)$ & $-0.04(-0.11$ to 0.03$)$ \\
\hline Low density lipoprotein cholesterol (mmol/l) & $3(2223)$ & $-0.05(-0.12$ to 0.01$)$ \\
\hline High density lipoprotein cholesterol (mmol/l) & $4(4050)$ & $0.10(0.08$ to 0.11$)$ \\
\hline Triglycerides (mmol/l) & $4(4049)$ & $-0.24(-0.30$ to -0.17$)$ \\
\hline Weight in those with diabetes $(\mathrm{kg})$ & $1(1047)$ & $-3.90(-4.57$ to -3.23$)$ \\
\hline Haemoglobin $\mathrm{A}_{1 \mathrm{C}}$ in those with diabetes (\%) & $1(1047)$ & $-0.70(-0.84$ to -0.56$)$ \\
\hline Fasting glucose in those with diabetes $(\mathrm{mmol} / \mathrm{l})$ & $1(1047)$ & $-0.97(-1.30$ to -0.64$)$ \\
\hline Discontinuation because of adverse event (absolute \% difference) & $4(4105)$ & $0.06^{*}(0.05$ to 0.08$)$ \\
\hline Serious adverse event (absolute \% difference) & $4(4105)$ & $0.02^{\star}(0.00$ to 0.03$)$ \\
\hline Psychiatric disorders (absolute \% difference) & $4(4105)$ & $0.03^{*}(0.02$ to 0.05$)$ \\
\hline
\end{tabular}

*Risk difference. All other calculations represent weighted mean difference. 


$\begin{array}{lr}\text { Drug } & \text { Standard dose } \\ \text { Orlistat } & 120 \mathrm{mg} \text { three times daily }\end{array}$

Sibutramine

10-15 mg once daily

Rimonabant

$20 \mathrm{mg}$ once daily
Potentially useful in

Pre-diabetes, diabetes, raised low density lipoprotein cholesterol,

hypertension, pre-existing cardiovascular disease

When lack of satiety is major barrier Uncontrolled hypertension,

to weight reduction, dyslipidaemia

(high triglyceride/low high density lipoprotein cholesterol)

Dyslipidaemia (high triglyceride

low high density lipoprotein

cholesterol), diabetes, metabolic

syndrome, hypertension

tachycardia, pre-existing

cardiovascular disease

History of psychiatric illness, live impairment
Malabsorption or chronic gastrointestinal disease 
9 Verhagen AP, de Vet HC, de Bie RA, Kessels AG, Boers M, Bouter LM, et al. The Delphi list: a criteria list for quality assessment of randomized clinical trials for conducting systematic reviews developed by Delphi consensus. J Clin Epidemiol 1998;51:1235-31.

10 Juni P, Smith GD, Altman DG. Assessing the quality of randomised controlled trials. In: Egger M, Smith GD, Altman DG, eds. Systematic reviews in health care. 2nd ed. London: BMJ Publishing, 2001:87108.

11 Higgins J, Thompson SG, Deeks JJ, Altman DG. Measuring inconsistency in meta-analyses. BMJ 2003;327:557-60.

12 Curioni C, Andre C. Rimonabant for overweight or obesity. Cochrane Database Syst Rev 2006;(4):CD006162.

13 Li Z, Maglione M, Tu W, Mojica W, Arterburn D, Shugarman LR, et al. Meta-analysis: pharmacologic treatment of obesity. Ann Intern Med 2005;142:532-46.

14 O'Meara S, Riemsma R, Shirran L, Mather L, ter Riet G. The clinical effectiveness and cost-effectiveness of sibutramine in the management of obesity: a technology assessment. Health Technol Assess 2002;6:1-97.

15 O'Meara S, Riemsma R, Shirran L, Mather L, ter Riet G. A rapid and systematic review of the clinical effectiveness and cost-effectiveness of orlistat in the management of obesity. Health Technol Assess 2001;5:1-81.

16 Lexchin J, Bero LA, Djulbegovic B, Clark O. Pharmaceutical industry sponsorship and research outcome and quality: systematic review. BMJ 2003;326:1167-70.
17 Wing RR, Marcus MD, Epstein LH, Salata R. Type II diabetic subjects lose less weight than their overweight nondiabetic spouses. Diabetes Care 1987;10:563-6.

18 Padwal R, Kezouh A, Levine M, Etminan M. Long-term persistence with orlistat and sibutramine in a population-based cohort. Int J Obes (Lond) 2007;31:1567-70.

19 National Institute for Health and Clinical Excellence. CG43 obesity: full guideline, section 1-introduction, methods and recommendations. 2006. http://guidance.nice.org.uk/CG43/ guidance/section1/word/English.

20 Colman E. Anorectics on trial. A half-century of federal regulation of prescription appetite suppressants. Ann Intern Med 2005;143:380-5.

21 Gillies CL, Abrams KR, Lambert PC, Cooper NJ, Sutton AJ, Hsu RT, et al. Pharmacological and lifestyle interventions to prevent or delay type 2 diabetes in people with impaired glucose tolerance: a systematic review and meta-analysis. BMJ 2007;334:299.

22 Padwal RS. Antiobesity drug therapy: a call for more rigorous endpoint evaluation. Therapy 2007;4:221-6.

23 Padwal R, Majumdar SR, Johnson JA, Varney J, McAlister FA. A systematic review of drug therapy to delay or prevent type 2 diabetes. Diabetes Care 2005;28:736-44.

Accepted: 26 September 2007 